\title{
Influence of insect traps and insecticides sequential application as a tactic for management of tomato leafminer, Tuta absoluta (Meyrick), (Lepidoptera: Gelechiidae)
}

\author{
Nasr Mohamed Abdelmaksoud ${ }^{1 *}$ (D), Nahed Fawzy Abdel-Aziz ${ }^{1}$, Elham Ahmed Sammour ${ }^{1}$, \\ Essam Abd El Maguied Agamy², Ahmed Mohamed El-Bakry ${ }^{1}$ and Mohamed Abdel-Hady Kandil ${ }^{2}$
}

\begin{abstract}
Background: Tomato crop, Lycopersicon esculentum L. (Solanaceae), usually attacked by many insect species, including the tomato leafminer, Tuta absoluta (Meyrick) (Lepidoptera: Gelechiidae), where its larvae cause damage up to $80-100 \%$ by due to its feeding habits by making tunnels in all tomato parts. The influence of insect traps application and insecticides sequential as a tactic for T. absoluta management was carried out.

Results: Sex pheromone and sticky traps were used for mass trapping this pest; sex pheromone traps were more effective than the sticky one; the number of caught insects was higher in the untreated plots than the treated one. Also, the general mean number of captured insects by sex pheromone traps was 432.89 and 633.40 (vegetative stage) and 691.3 and 1865.5 (fruiting stage) adults/trap/week, for treatment and control, respectively. When the first infestation appeared, the non-conventional insecticides were consecutively sprayed once/week for 3 weeks with the following order: Radiant, Coragen, and Emperor (during the vegetative stage). After that, the formulated essential oils Nimbecidine (commercial) and Rosa (prepared) were respectively sprayed twice/week for 2 weeks (during the fruiting stage). The general average of reduction in infestation reached $95.81 \%$ when non-conventional insecticides were used, while it reached $92.15 \%$ when the formulated essential oils were used. Finally, at the end of the experiment, promising mean reduction in infestation reached $93.98 \%$ was achieved. Yield of marketable healthy fruits was recorded and expressed as ton/feddan. Treatments gave significantly higher yield over untreated control. The tomato yield reached $28.25 \mathrm{t} / \mathrm{fed}$. compared with control (8.35 t/fed.), which gain $19.94 \mathrm{t} / \mathrm{fed}$. equal to $238.32 \%$ more than the untreated control.
\end{abstract}

Conclusions: The results indicated that insect traps and insecticides sequential application as a tactic for management $T$. absoluta were more effective; the rotation of insecticides avoid build up resistance and achieved satisfied reduction (93.98\%) in the infestation and high yield production.

Keywords: Tuta absoluta, Sequential application, Insect traps, Non-conventional insecticides, Formulated essential oils

\footnotetext{
* Correspondence: nm_nrc@yahoo.com

${ }^{1}$ Agricultural and Biological Research Division, Department of Pests and Plant

Protection, National Research Centre, Cairo, Egypt

Full list of author information is available at the end of the article
}

\section{Springer Open}

(- The Author(s). 2020 Open Access This article is licensed under a Creative Commons Attribution 4.0 International License, which permits use, sharing, adaptation, distribution and reproduction in any medium or format, as long as you give appropriate credit to the original author(s) and the source, provide a link to the Creative Commons licence, and indicate if changes were made. The images or other third party material in this article are included in the article's Creative Commons licence, unless indicated otherwise in a credit line to the material. If material is not included in the article's Creative Commons licence and your intended use is not permitted by statutory regulation or exceeds the permitted use, you will need to obtain permission directly from the copyright holder. To view a copy of this licence, visit http://creativecommons.org/licenses/by/4.0/. 


\section{Introduction}

Tomato plants (Lycopersicon esculentum L.), which belongs to family Solanaceae, is an important and profitable vegetables for fresh marketing processing. It is the 6th most valuable cultivated plant. In Africa, total production is nearly 37.8 million tons annually; Egypt, Nigeria, Tunisia, and Morocco were the greatest producers. Tomato plants usually attacked by a great varieties of insects especially tomato leafminer, Tuta absoluta (Meyrick 1917) (FAOSTAT 2017; Kushwaha et al. 2018). T. absoluta was firstly recorded in both Algeria, Morocco, and Libya in 2008 and 2009 and continued to invade Egypt in 2010 (Moussa et al. 2013; Salem and Abdel-Moniem 2015; Sylla et al. 2017; Biondi et al. 2018). The larvae of this insect have destructive effects on tomatoes and causing yield losses being 80$100 \%$. T. absoluta is difficultly manageable due to two reasons: larvae feeding habits and insects ability to build up resistance. Such resistance enforces the farmer to aggravatingly and repeatedly spray chemical insecticides; hence, the insect becomes highly resistant towards synthetic insecticide and shows the reduced effectiveness of control (Abd El-Salam et al. 2015; Ayalew 2015; Tonnang et al. 2015; Chidege et al. 2017; Aynalem 2018; Ndor 2018; Sammour et al. 2018).

Management of $T$. absoluta becomes problematic, especially when the infestation level is high, as well as the failure of synthetic pesticides application for controlling this pest because of development of insect resistance, high operating costs, and the environmental contamination. Therefore, we need to develop alternative solutions. Application of natural compounds, such as plant essential oils, is considered as an alternative to chemical pesticides because of their lower toxicity against non-target organisms and low persistence in the environment (Chegini and Abbasipour 2017; Birhan 2018).

The decision scheme of insecticides which used for managing of $T$. absoluta is largely based on adult captures with sexual pheromone traps, which correlated of both larval damages and yield losses. Using chemical insecticides in combination with other tactics such as natural formulations and mass trapping with sex pheromones as integrated pest management (IPM) is the most useful control method, where it controlled the $T$. absoluta and increased the yield production and the quality of the marketable tomato fruits (Miranda et al. 2005; Benvenga et al. 2007; Taha et al. 2013; Giorgini et al. 2018; Abd El-Salam et al. 2019).

The purpose of the present study is to investigate certain IPM tactic in the management of T. absoluta, such as sex pheromone and sticky traps for monitoring and mass trapping the insects, associated with selective nonconventional insecticides (during vegetative stage) and formulated essential oils (during fruiting stage) as well as estimate the tomato yield production.

\section{Materials and methods}

From our preliminary studies (laboratory and field), some commercial and natural formulations with different modes of action were evaluated against the 2nd larval instar of Tuta absoluta. The results revealed that the most effective compounds were Emperor 0.5\% EC (avermectins, Shandong Jingbo Agrochemical Co., China), Coragen 20\% SC (diamide, Dupont, Canada), and Radiant 12\% SC (spinosyns, Dow Agrosciences, England) as non-conventional insecticides as well as the natural compounds Rosa 5\% EC (prepared formulation of Rosmarinus officinalis) and Nimbecidine 3.5\% EC (commercial formulation of Azadirachtin), so, they have been selected for the sequential application against T. absoluta, using the $\mathrm{LC}_{90}$ values (Table 1) (Abdelmaksoud 2019).

\section{Field experiments}

Field experiments were carried out on infested tomato plants (Super strain B) with T. absoluta cultivated at Elfashn village, BaniSweif Governorate, Egypt, to investigate the efficiency of insect traps associated with chemical insecticides or natural compounds. A known area ( $1 / 4$ fed.) was divided into six plots including three replicates (for treatment and control); each one was $175 \mathrm{~m}^{2}$.

\section{Mass trapping of $T$. absoluta adults}

To start the process of sequential application of selected treatments, sex pheromone and sticky traps were used for monitoring and mass trapping these insects. The survey study was carried out from the cultivation beginning (1st week of April) to the end of the season (3rd week of July). The average of temperature and humidity were recorded.

\section{Sex pheromone traps}

A density of 20 traps/fed. was conducted under open field conditions. Plastic basins with $40 \times 30 \times 15 \mathrm{~cm}$ were used as water pan traps filling with water and baited with the synthetic sex pheromone. Traps were ranked on the tops of $20 \mathrm{~cm}$ wood sticks and placed just above the plant canopy. Pheromone capsules were renewed at 2 weeks interval. The level of water in the traps was adjusted when it was necessary. All adults captured were counted and recorded weekly to monitor adult populations and to determine the suitable time for starting using insecticides.

\section{Sticky traps}

Paper board traps $(22.5 \times 35 \mathrm{~cm}$. $)$ were used. Traps were coated on one face with a thin layer of insect viscous 
Table 1 Toxicity of tested commercial insecticides against the 2nd instar larvae of Tuta absoluta using leaf dipping technique

\begin{tabular}{|c|c|c|c|}
\hline Trade name & Common name & Mode of action & $\mathrm{LC}_{90}$ \\
\hline Chemical insecticides & & & $(\mathrm{mg} / \mathrm{L})$ \\
\hline Emperor $(0.5 \% \mathrm{EC})$ & Emamectin benzoate & Chloride channel activators (group no. 6) & $1.66(1.06-3.87)$ \\
\hline Coragen (20\% SC) & Chlorantraniliprole & Ryanodine receptor modulators (group no. 28) & $1.82(1.49-2.40)$ \\
\hline Radiant (12\% SC) & Spinetoram & $\begin{array}{l}\text { Nicotinic acetylcholine receptor (nAChR) allosteric } \\
\text { activators. Nerve action (group no. 5) }\end{array}$ & $4.84(3.64-6.54)$ \\
\hline Natural formulated compounds & & & (\%) \\
\hline Rosa $(5 \% \mathrm{EW})^{*}$ & Rosmarinus officinalis & UN compounds of unknown or uncertain MoA & $0.417(0.29-0.67)$ \\
\hline Nimbecidine (3.5\% EC) & Azadirachtin & UN compounds of unknown or uncertain MoA & $0.571(0.43-0.92)$ \\
\hline
\end{tabular}

\section{UN unknown}

*The compound Rosa (EW) was prepared by mixing rosemary essential oil with methyl salicylate (winter green oil) and water in appropriate amounts of emulsifier and natural solvents (vegetable and mineral oils in water)

(sticky special). The sticky traps were fastened vertically to stakes just above the plant canopy in a randomized pattern. Trapping surface was faced towards the east. The traps were applied at 24 traps/fed. T. absoluta moths on each trap surface were counted, and their monitoring was performed on regular weekly basis intervals.

\section{Insecticides sequential application}

When the first infestation appears during the vegetative stage, the most efficient commercial insecticides (Radiant, Coragen, and Emperor) were sprayed by three folds of $\mathrm{LC}_{90}$ values successively once/week for 3 weeks. Firstly, Radiant followed by Coragen then Emperor. While during the fruiting stage, the most promising natural oil-based formulations (Nimbecidine and Rosa) were sprayed successively twice/week for 2 weeks, first Nimbecidine then Rosa (Table 2 and Fig. 1). The levels of infestation were recorded. Control plants were sprayed with an equal volume of water only.

Leaves of five plants (10 leaves/plant) of treated and untreated plots were collected randomly and transferred in paper bags to the laboratory. Samples were taken before spray and after treatment twice a week (3 and 7 days from each week) for examining and counting of alive larvae. The mortality percentages of T. absoluta larvae were determined at each collection interval. The percent reduction of infestations was calculated according to Henderson-Tilton formula (Henderson and Tilton 1955).

\section{Yield production}

At the harvest, yield of marketable ripe fruits was recorded and expressed as ton/fed. All fruits harvested (about five successive harvest) from each plot along the harvesting period were weighted to calculate the total yield per fed. (ton/fed.), as well as the total cost, and the net profits for fed. and for ton of tomato yield were also calculated. The income statement was used to estimate the profit of tomato production.

$$
\text { Increase of yield }(\%)=\frac{\text { Yield of treated tomato }- \text { Yield of untreated tomato }}{\text { Yield of untreated tomato }} \times 100
$$

\section{Cost of treatments}

Cost of various insecticides was taken as per market price, and labor charges were calculated. The total cost of spraying was calculated on the basis labor requirement per fed./day. Market price of insecticides and labor charges were summed up to work out the total cost of application of each treatment. This cost was taken as an additional cost required for treatment against the tested insect.

\section{Additional income over control}

Additional income over control was calculated by multiplying the additional yield over untreated control with prevailing average local market price of tomato fruits.

\section{Net profit}

This was calculated by subtracting the additional cost required for treatment from the monetary benefit for each treatment.

\section{Cost benefit ratio}

The cost benefit ratio (CBR) was calculated by dividing the net monetary return by total additional cost due to treatment.

\section{Statistical analysis}

The insecticide efficacy data were subjected to Probit analysis to obtain the $\mathrm{LC}_{90}$ values using the Statistical Package for the Social Sciences (SPSS) 25.0 software program (SPSS 2017). The values of $\mathrm{LC}_{50}$ were considered significantly different if the $95 \%$ confidence limits did not overlap. 
Table 2 Proposed sequences of the tested insecticides and naturally formulations

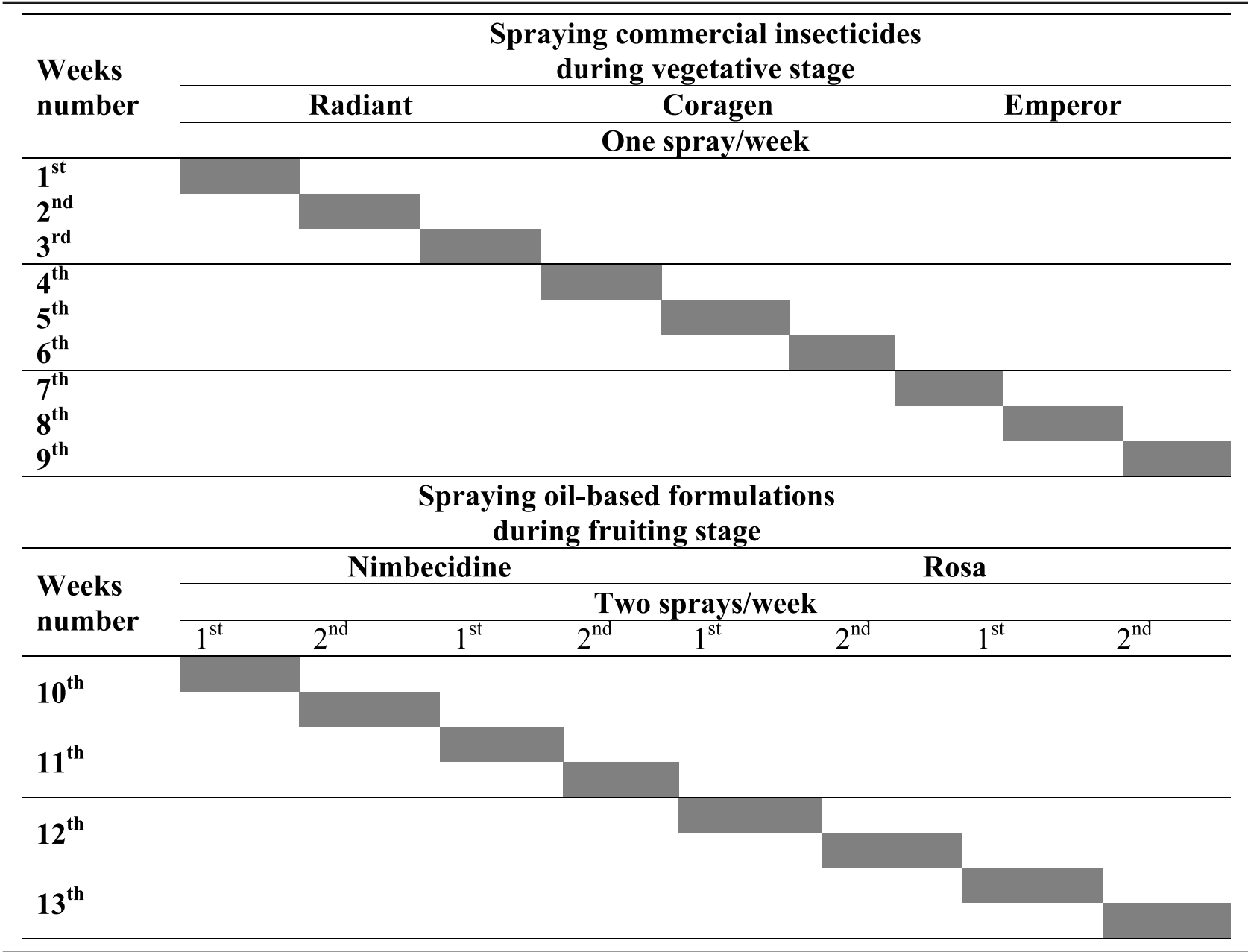

\section{Results}

Mass trapping of $T$. absoluta adults

Sex pheromone traps

The data set out in Table 3 indicated that the mean numbers of the adult caught in the first inspection before begging the insecticides sequence applications were 263 and 241 adults/trap/week for sequential treatment and control, respectively, then increased gradually with time elapsed. The general mean number of captured insects was 432.89 and 633.40 (vegetative stage) and 691.30 and 1865.50 (fruiting stage) adults/trap/week, respectively, where the average of temperature and humidity was $26.2{ }^{\circ} \mathrm{C}$ and $39.1 \%$ (vegetative stage) and $28.6{ }^{\circ} \mathrm{C}$ and $34.5 \%$ (fruiting stage), respectively.

This increase in the number of caught insects at the end of the season in spite of using the program of insecticides sequence may be due to the attractant of the sex pheromone from the neighboring farms since these experiments were not conducted under control conditions (open field). The success of this trap partially related with the pesticide sequences; however, if the situation was under control, it will be possible to emphasize the role of the trap with the IPM program.

\section{Sticky traps}

The data in Table 3 showed that in the first inspection, the mean catches of T. absoluta at the begging of the experiment were 8.4 and 8.0 adults/trap/week for treatment and control, respectively. While the mean number of captured insect drastically increase at the end of the season until reached 29.8 and 31.5 adults/trap/week for treated and untreated plots, respectively.

In view of the above results, it is clear that sex pheromone traps captured significantly more moths than sticky traps.

\section{Insecticides sequential application}

In this program, from our previously results, the tested chemical insecticides which showed high efficiency in reducing insect counts under field conditions were consecutively sprayed with the following order: Radiant, 


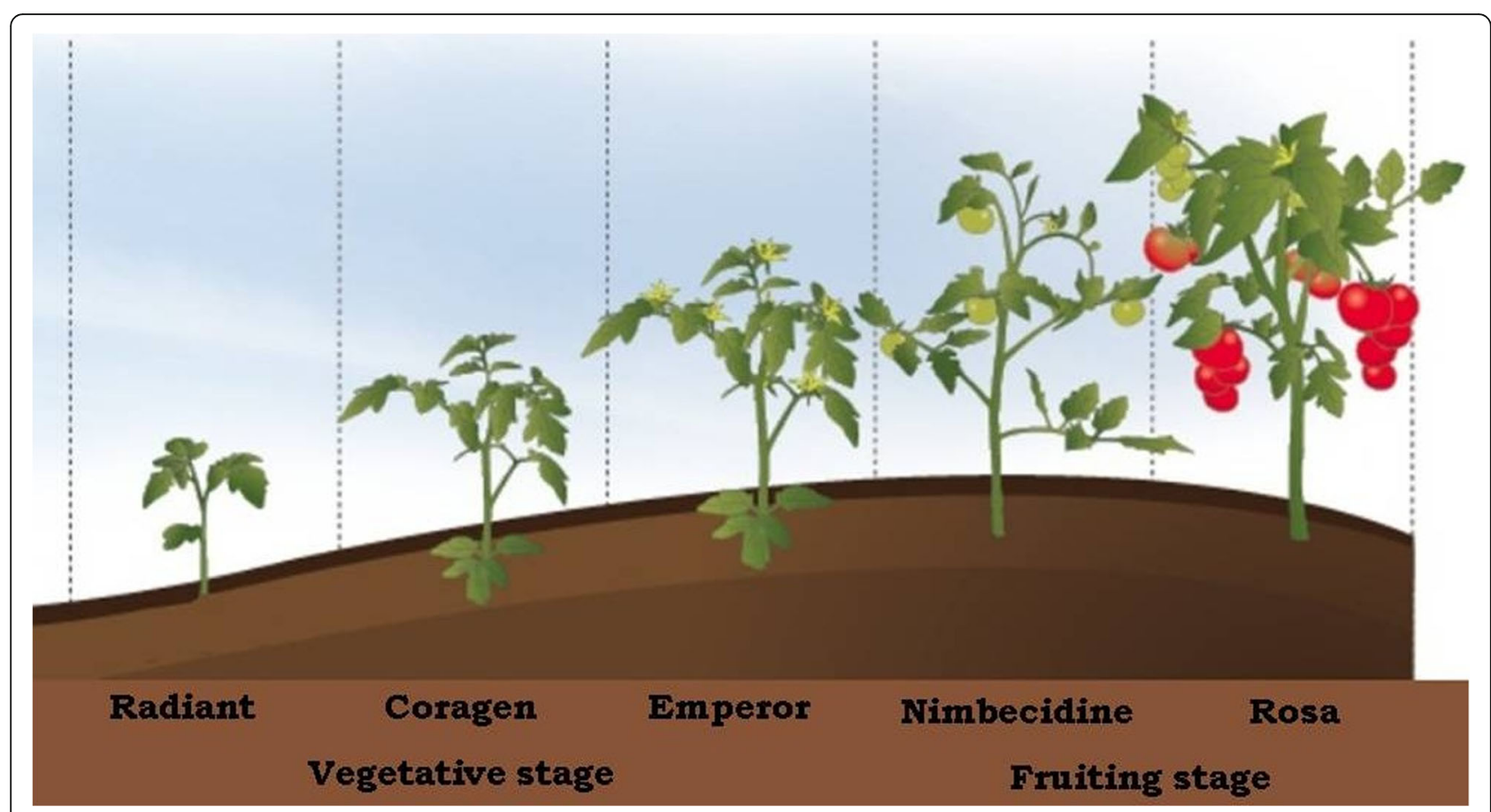

Fig. 1 Sequence of insecticides and the naturally formulations throughout the season

Table 3 Total count of T. absoluta moths collected by the sex pheromone and sticky traps associated with sequential applications during cultivated season

\begin{tabular}{|c|c|c|c|c|c|c|c|}
\hline \multirow[t]{4}{*}{ Month } & \multirow{3}{*}{$\begin{array}{l}\text { Inspection } \\
\text { time (week) }\end{array}$} & \multicolumn{4}{|c|}{ Mean no. captured adults/trap } & \multirow{4}{*}{$\begin{array}{l}\text { Temp. } \\
\text { average }\left({ }^{\circ} \mathrm{C}\right)\end{array}$} & \multirow{4}{*}{$\begin{array}{l}\text { Humidity } \\
\text { average (\%) }\end{array}$} \\
\hline & & \multicolumn{2}{|c|}{ Sex pheromone traps } & \multicolumn{2}{|l|}{ Sticky traps } & & \\
\hline & & Treatment $\pm(\mathrm{SD})$ & Control $\pm(S D)$ & Treatment $\pm(S D)$ & Control $\pm(S D)$ & & \\
\hline & Vegetative stage & & & & & & \\
\hline \multirow[t]{3}{*}{ April } & 3rd week & $263 \pm 16$ & $241 \pm 20$ & $8.4 \pm 2.3$ & $8.0 \pm 1.7$ & 24.5 & 44.4 \\
\hline & 4th week & $259 \pm 19$ & $268 \pm 17$ & $7.4 \pm 1.7$ & $9.0 \pm 3.3$ & 26.8 & 38.3 \\
\hline & Mean & $261 \pm 17.5$ & $254.5 \pm 18.5$ & $7.9 \pm 2.0$ & $8.5 \pm 2.5$ & 25.7 & 41.4 \\
\hline \multirow[t]{5}{*}{ May } & 1st week & $312 \pm 11$ & $327 \pm 15$ & $10.6 \pm 3.0$ & $15.0 \pm 2.7$ & 24.8 & 43.0 \\
\hline & 2nd week & $463 \pm 31$ & $583 \pm 24$ & $11.0 \pm 2.3$ & $17.5 \pm 3.7$ & 24.4 & 43.7 \\
\hline & 3rd week & $397 \pm 27$ & $533 \pm 29$ & $11.4 \pm 3.7$ & $18.0 \pm 3.0$ & 26.5 & 39.2 \\
\hline & 4th week & $436 \pm 34$ & $567 \pm 31$ & $15.8 \pm 2.0$ & $22.5 \pm 2.0$ & 25.6 & 37.5 \\
\hline & Mean & $402 \pm 25.8$ & $502.5 \pm 24.8$ & $12.2 \pm 2.8$ & $18.25 \pm 2.9$ & 25.3 & 40.9 \\
\hline \multirow[t]{7}{*}{ June } & 1st week & $588 \pm 22$ & $873 \pm 17$ & $15.8 \pm 3.3$ & $26.0 \pm 3.0$ & 27.6 & 35.6 \\
\hline & 2nd week & $547 \pm 36$ & $963 \pm 34$ & $14.2 \pm 2.7$ & $30.0 \pm 2.0$ & 28.4 & 34.2 \\
\hline & 3rd week & $631 \pm 29$ & $1346 \pm 42$ & $17.0 \pm 3.7$ & $33.5 \pm 3.3$ & 27.4 & 35.9 \\
\hline & General mean & $432.89 \pm 25$ & $633.40 \pm 25.4$ & $12.40 \pm 2.7$ & $19.94 \pm 2.7$ & 26.20 & 39.10 \\
\hline & Fruiting stage & & & & & & \\
\hline & 4th week & $625 \pm 19$ & $1795 \pm 47$ & $16.4 \pm 4.3$ & $35.0 \pm 2.3$ & 26.9 & 36.1 \\
\hline & Mean & $597.8 \pm 26.5$ & $1244.2 \pm 35$ & $15.85 \pm 3.5$ & $31.13 \pm 2.7$ & 27.6 & 35.5 \\
\hline \multirow[t]{5}{*}{ July } & 1st week & $691 \pm 34$ & $1935 \pm 51$ & $23.2 \pm 3.7$ & $36.5 \pm 3.0$ & 27.3 & 35.7 \\
\hline & 2nd week & $715 \pm 42$ & $1905 \pm 37$ & $27.0 \pm 2.7$ & $33.3 \pm 2.7$ & 28.6 & 34.7 \\
\hline & 3rd week & $734 \pm 28$ & $1827 \pm 49$ & $29.8 \pm 4.3$ & $31.5 \pm 4.3$ & 31.5 & 31.6 \\
\hline & Mean & $713.3 \pm 34.7$ & $1244 \pm 45.7$ & $26.67 \pm 3.6$ & $33.77 \pm 3.1$ & 29.1 & 34.0 \\
\hline & General mean & $691.3 \pm 26.8$ & $1865.5 \pm 31.8$ & $24.10 \pm 3.1$ & $34.08 \pm 2.8$ & 28.6 & 34.5 \\
\hline
\end{tabular}


Coragen, and Emperor (during the vegetative stage). After that, the tested naturally based formulated compounds Nimbecidine and Rosa were respectively sprayed (during the fruit stage) (Table 2 and Fig. 1), as well as insect traps. This integration will be mandatory to minify build up resistance in T. absoluta populations and increase the efficiency of pest control.

Results revealed that the mentioned sequences achieved considerable reduction percentages in tomato plants infested by T. absoluta (Table 4). The mean percent reduction in infestation after three successive spraying during 3 weeks (one spray/week for each insecticide) was $91.61 \%$ for Radiant, $99.38 \%$ for Coragen, and $96.45 \%$ for Emperor. Concerning treatment with naturally based formulated compounds, four successive spraying during 2 weeks were applied ( 2 sprays/week for each formulation). The mean percent reduction in infestation reached 93.67\% for Nimbecidine and $90.63 \%$ for Rosa (Table 5).

In conclusion, the general average of reduction in infestation reached $95.81 \%$ when non-traditional chemical insecticides were used during the vegetative stage, while it reached $92.15 \%$ when naturally based formulated compounds were used during the fruit stage. Finally, at the end of the experiment, we achieved the promising mean reduction in infestation reached $93.98 \%$.

\section{Yield production}

The data of tomato yield as influenced by various treatments are presented in Table 6. It could be seen from the table that treatments gave significantly higher yield over untreated control. The tomato yield reached 28.25 $\mathrm{t} /$ fed. when compared with control (8.4t/fed.), which gain $19.94 \mathrm{t} / \mathrm{fed}$. and $238.32 \%$ more than the untreated control.

It is seen from Table 6 that treatments achieved the maximum net monetary returns of 31647 EG pound per fed. and $1120.25 \mathrm{EG} \mathrm{lb} / \mathrm{t}$, in comparison to untreated control which implemented $6146 \mathrm{EG} \mathrm{lb} / \mathrm{fed}$. and 736.05 $\mathrm{EG} \mathrm{lb/t}$. Also, treated plants achieved the highest cost benefit ratio of 1:7.6. The treated plots recorded maximum gross income; it was $42093 \mathrm{EG} \mathrm{lb} / \mathrm{fed}$. compared to untreated control (12442 EG lb/fed.).

In conclusion, treatments represent a promising effect in controlling the pests as well as gain a net profit as compared with the control.

\section{Discussions}

Complementary strategies of pest management aim to diminish the use of insecticides through an efficient monitoring of pest population in order to choose the correct time of pesticide application. Lepidoptera pheromones have been successfully used for insect monitoring and mating disruption of insects (Taha et al. 2013; Braham 2014; Giorgini et al. 2018).
Table 4 Effect of sequential application of certain commercial non-traditional chemical insecticides on Tuta absoluta applied three times (during vegetative stage)

\begin{tabular}{|c|c|c|c|c|c|c|c|c|}
\hline \multirow{2}{*}{$\begin{array}{l}\text { Spray } \\
\text { number }\end{array}$} & \multirow{2}{*}{$\begin{array}{l}\text { Day after } \\
\text { treatment }\end{array}$} & \multirow{2}{*}{$\begin{array}{l}\text { Control } \\
\text { Alive }\end{array}$} & \multicolumn{2}{|c|}{ Radiant } & \multicolumn{2}{|c|}{ Coragen } & \multicolumn{2}{|c|}{ Emperor } \\
\hline & & & Alive & ${ }^{*} \mathrm{R} \%$ & Alive & $\mathrm{R} \%$ & Alive & $\mathrm{R} \%$ \\
\hline B-spray & Zero & 6.67 & 7.33 & 0.00 & 7.33 & 0.00 & 7.33 & 0.00 \\
\hline \multirow[t]{3}{*}{$1 s t$} & 3 days & 10.00 & 1.67 & 84.48 & - & - & - & - \\
\hline & 7 days & 9.33 & 1.33 & 87.01 & - & - & - & - \\
\hline & Mean & 1.83 & 1.83 & 85.75 & - & - & - & - \\
\hline \multirow[t]{3}{*}{ 2nd } & 3 days & 10.33 & 1.00 & 90.91 & - & - & - & - \\
\hline & 7 days & 10.67 & 0.33 & 96.75 & - & - & - & - \\
\hline & Mean & 10.50 & 0.67 & 93.83 & - & - & - & - \\
\hline \multirow[t]{3}{*}{$3 r d$} & 3 days & 11.67 & 0.67 & 93.75 & - & - & - & - \\
\hline & 7 days & 13.67 & 0.33 & 96.75 & - & - & - & - \\
\hline & Mean & 12.7 & 0.50 & 95.3 & - & - & - & - \\
\hline \multicolumn{2}{|c|}{ General average } & 8.33 & 1.00 & 91.61 & - & - & - & - \\
\hline \multirow[t]{3}{*}{ 4th } & 3 days & 13.67 & - & - & 0.00 & 100.0 & - & - \\
\hline & 7 days & 14.67 & - & - & 0.00 & 100.0 & - & - \\
\hline & Mean & 14.17 & - & - & 0.00 & 100.0 & - & - \\
\hline \multirow[t]{3}{*}{5 th } & 3 days & 13.31 & - & - & 0.33 & 97.73 & - & - \\
\hline & 7 days & 14.67 & - & - & 0.00 & 100.0 & - & - \\
\hline & Mean & 13.99 & - & - & 0.17 & 98.87 & - & - \\
\hline \multirow[t]{3}{*}{ 6th } & 3 days & 13.67 & - & - & 0.00 & 100.0 & - & - \\
\hline & 7 days & 14.00 & - & - & 0.67 & 98.56 & - & - \\
\hline & Mean & 13.84 & - & - & 0.34 & 99.28 & - & - \\
\hline \multicolumn{2}{|c|}{ General average } & 14.00 & - & - & - & 99.38 & - & - \\
\hline \multirow[t]{3}{*}{ 7th } & 3 days & 13.67 & - & - & - & - & 0.33 & 97.78 \\
\hline & 7 days & 18.00 & - & - & - & - & 0.67 & 96.63 \\
\hline & Mean & 15.84 & - & - & - & - & 0.50 & 97.21 \\
\hline \multirow[t]{3}{*}{ 8th } & 3 days & 21.33 & - & - & - & - & 1.00 & 95.74 \\
\hline & 7 days & 19.33 & - & - & - & - & 1.33 & 93.73 \\
\hline & Mean & 20.33 & - & - & - & - & 1.17 & 94.74 \\
\hline \multirow[t]{3}{*}{ 9th } & 3 days & 18.67 & - & - & - & - & 0.67 & 96.75 \\
\hline & 7 days & 20.67 & - & - & - & - & 0.33 & 98.04 \\
\hline & Mean & 19.67 & - & - & - & - & 0.50 & 97.40 \\
\hline \multicolumn{2}{|c|}{ General average } & 18.61 & - & - & - & - & 0.72 & 96.45 \\
\hline \multicolumn{2}{|c|}{ General reduction } & 95.81 & & & & & & \\
\hline
\end{tabular}

${ }^{*}$ R\%, reduction percentages during 3 successive weeks

Rotations are a common tactic for usage in managing pesticide resistance and considered to have a good recorded in slowing down the evolution of resistance. It is also necessary to rotate the use of active substances with various modes of action (chemical group) in the IPM tactic. So, the insecticide should be selected carefully, especially in the early growth stages of the crop (IRAC 2017, 2019; Bassi et al. 2016).

The utilization of pheromone traps in monitoring T. absoluta adult, it might be possible to determine 
Table 5 Effect of sequential application of certain naturally based formulated compounds on Tuta absoluta applied twice (during fruiting stage)

\begin{tabular}{|c|c|c|c|c|c|c|}
\hline \multirow{2}{*}{$\begin{array}{l}\text { Spray } \\
\text { number }\end{array}$} & \multirow{2}{*}{$\begin{array}{l}\text { Day after } \\
\text { treatment }\end{array}$} & \multirow{2}{*}{$\begin{array}{l}\text { Control } \\
\text { Alive }\end{array}$} & \multicolumn{2}{|c|}{ Nimbecidine } & \multicolumn{2}{|l|}{ Rosa } \\
\hline & & & Alive & $\mathrm{R} \%$ & Alive & $\mathrm{R} \%$ \\
\hline B-spray & Zero & 6.67 & 7.33 & 0.00 & 7.33 & 0.00 \\
\hline \multirow[t]{3}{*}{ 10th } & 3 days & 23.00 & 1.67 & 93.41 & - & - \\
\hline & 7 days & 22.67 & 1.33 & 94.65 & - & - \\
\hline & Mean & 22.84 & 1.50 & 94.03 & - & - \\
\hline \multirow[t]{3}{*}{ 11th } & 3 days & 22.33 & 2.00 & 91.86 & - & - \\
\hline & 7 days & 23.00 & 1.33 & 94.73 & - & - \\
\hline & Mean & 22.67 & 1.67 & 93.30 & - & - \\
\hline \multicolumn{2}{|c|}{ General average } & 22.76 & 1.59 & 93.67 & & \\
\hline \multirow[t]{3}{*}{ 12th } & 3 days & 31.00 & - & - & 3.00 & 90.14 \\
\hline & 7 days & 29.67 & - & - & 2.00 & 93.10 \\
\hline & Mean & 30.34 & - & - & 2.50 & 91.62 \\
\hline \multirow[t]{3}{*}{ 13th } & 3 days & 29.67 & - & - & 3.33 & 88.49 \\
\hline & 7 days & 29.67 & - & - & 2.67 & 90.79 \\
\hline & Mean & 29.67 & - & - & 3.00 & 89.64 \\
\hline \multicolumn{2}{|c|}{ General average } & 30.01 & & & 2.75 & 90.63 \\
\hline \multicolumn{2}{|c|}{ General reduction } & 92.15 & & & & \\
\hline
\end{tabular}

the ideal time for spraying pesticides, which leads to the reduction and rational use of insecticides. In addition, mass trapping techniques can be used with appropriately (Braham 2014). Pheromone traps are not only used for detection of the insect but also for controlling the T. absoluta population through mating disruption and mass annihilation (Ghoneim 2014; Retta and Berhe 2015).

Our findings are in agreement with El-Aassar et al. (2015) who found that using sex pheromone combined with other insecticides in controlling the leafminers infestation on tomato plants showed promising results, since sex pheromone traps were very effective in monitoring as well as mass trapping this pest, and it was useful in determining the most suitable time to begin spray insecticide.

As a rule, in chemical application, it is prudent to rotate different active ingredients and not to mix them at once to avoid the build up of resistance against the pesticides. The suggested active ingredients for rotation in the management of $T$. absoluta include using Radiant (Spinetoram) which exhibited an effective control of lepidopteran insects after a short time of treatment. It has a novel mode of action (neural mechanism), disrupting acetylcholine neurotransmission, and it has effects on a $\gamma$-aminobutyric acid (GABA) neurotransmitter agonist. It kills insects by hyper-excitation (causing tremors, paralysis) of the insect nervous system (Braham et al. 2012; Babar et al. 2016).

After that Coragen (Chlorantraniliprole) which works as both contact and stomach effects, it also has systemic translocation in the plant (phloem/xylem mobility) after soil application and has translaminar activity and penetrates the cuticle/epidermis. It induces muscular paralysis through disturbing the calcium balance, block sodium channel in nerve axon, and inhibit propagation of nerve potential; this explains its effect on the reduction of T. absoluta infestation.

The results of Valchev et al. (2013), Silva et al. (2016), Shiberu and Getu (2017), and Roditakis et al. (2018) are closed with our results where they determined a very good biological activity of Coragen towards the larvae of T. absoluta after $48 \mathrm{~h}$ of application.

The superiority of Emperor (emamectin benzoate), which has a high potency against a broad spectrum of lepidopterous pests, may be due to its predominantly to potentiating and/or direct opening of glutamate-gated chloride channels and the high affinity with the target site, and it may have irreversible effect, as well as, it binds to multiple sites (including glutamate and GABA) in insect chloride channels. Consequently, the insect is paralyzed irreversibly and stop feeding within hours of ingesting reaching to 2-4 days, so it prevents crop damage (Gacemi and Guenaoui 2012; Hamdy and El-Sayed 2013; Berxolli and Shahini 2018).

The utilizations of natural compounds such as plant essential oils are considered as an alternative to chemical pesticides because of their lower toxicity to the nontarget organisms and low persistence in the environment (Chegini and Abbasipour 2017).

These natural chemicals (essential oils) have multiple modes of action, including antifeedant and repellent activities, antimoulting and respiration inhibition, growth and fecundity reduction, and cuticle disruption. So, they can act as a contact, fumigant,

Table 6 Economics of insecticides and botanical formulations sequence treatments used against Tuta absoluta on tomato plants

\begin{tabular}{|c|c|c|c|c|c|c|c|c|}
\hline Treatments & $\begin{array}{l}\text { Yield (t/ } \\
\text { fed.) }\end{array}$ & $\begin{array}{l}\% \text { Increase yield } \\
\text { over control }\end{array}$ & $\begin{array}{l}\text { Total cost per } \\
\text { fed. (lb/fed.) }\end{array}$ & $\begin{array}{l}\text { Total cost per } \\
\text { ton }(\mathrm{lb} / \mathrm{t})\end{array}$ & $\begin{array}{l}\text { Gross income } \\
\text { (lb/fed.) }\end{array}$ & $\begin{array}{l}\text { Net monetary } \\
\text { returns (lb/fed.) }\end{array}$ & $\begin{array}{l}\text { Net monetary } \\
\text { returns (lb/t) }\end{array}$ & $\begin{array}{l}\text { Cost } \\
\text { benefit } \\
\text { ratio }\end{array}$ \\
\hline Treated & $\begin{array}{l}28.25 \pm \\
0.5\end{array}$ & 238.32 & $10446 \pm 0.0$ & $369.77 \pm 0.0$ & $42093 \pm 745$ & $31647 \pm 745$ & $1120.25 \pm 6.5$ & $1: 7.63$ \\
\hline $\begin{array}{l}\text { Untreated } \\
\text { (control) }\end{array}$ & $\begin{array}{l}8.35 \pm \\
0.8\end{array}$ & - & $6296 \pm 0.0$ & $754.01 \pm 0.0$ & $12442 \pm 1132$ & $6146 \pm 1132$ & $736.05 \pm 44.2$ & - \\
\hline
\end{tabular}


repellent, antifeedant, and oviposition inhibitory toxicants (Sarwar and Salman 2015).

Rosemary essential oil is primarily composed of a mixture of monoterpenes such as 1.8-cineol (37.6 \%) which represents the major compound followed by camphor (20.2\%) and then $\alpha$-pinene (15.7) that known to have insecticidal activities. Accordingly, the most interesting results of our study on the high toxicity of rosemary oil to T. absoluta can be readily attributed to more than one or two active principles (Yang et al. 2014).

Comparing the mode of action of the most effective naturally based formulated compound Rosa with the most efficient non-traditional chemical insecticides Emperor (emamectin benzoate), it is obvious that they have the same mode of action. They potentiate the actions of GABA at a recombinant insect ion tropic GABA receptor, which perhaps the most sensitive target site in $T$. absoulta that can affect by these compounds. So, we can conclude that either emamectin benzoate or Rosa have the same mode of action, so, this naturally based formulated compound has a good performance.

The superior benefits of this tactic depend on the direct production returns, the treatments with different insecticides resulted in a significantly maximum yield as well as the highest cost benefit ratio when compared with the untreated control one. Also, the maximum marketable yield and maximum additional income over control were obtained from the control treatments, and it gives the highest net profit over control as well as the maximum increase of the cost benefit ratio. These results are in conformity with Patra et al. (2009), Deshpande et al. (2010), Shivanna et al. (2011), and Dayaram (2014).

\section{Conclusions}

In this respect, according to the number of insects caught, it is clear that uses of insecticides or botanical formulation affect the insect infestation and consequently affect the number of captured insects/trap. To overcome or mitigate the incidence of insecticide resistance, it is necessitating rotating between several insecticides which have various modes of action that kill pests through different ways, especially when using several sprays during the season.

Integrated pest management (IPM) is the most useful method using rotating between chemical control in combination with other tactics such as mass trapping with sex pheromones and natural insecticides. The usage of IPM tactics in controlling the pests such as T. absoluta can increase the yield production and the quality of the marketable fruits.
So, during this study, the succeed IPM tactics in the management of $T$. absoluta were conducted, such as sex pheromone and sticky traps for monitoring and mass trapping the insects, associated with selective nonconventional insecticides (during vegetative stage) and formulated essential oils (during fruiting stage) as well as estimate the tomato yield production.

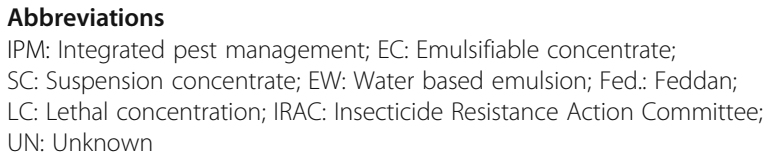

\section{Authors' contributions}

M. A. Kandil, E. A. Sammour, N. F. Abdel-Aziz, E. Agamy, A. M. El-Bakry, and N. M. Abdelmaksoud designed experiments, carried out the biological experiments, analyzed the data, and wrote the article. All authors read and approved the final manuscript.

\section{Funding}

This research was financed by the National Research Centre, Egypt, Project No. 11030140

\section{Availability of data and materials}

All data generated or analyzed during this study are included in this article.

Ethics approval and consent to participate

Not applicable (this study does not involve human participants, data, and tissue).

\section{Consent for publication}

Not applicable.

\section{Competing interests}

The authors declare that they have no competing interests.

\section{Author details}

${ }^{1}$ Agricultural and Biological Research Division, Department of Pests and Plant Protection, National Research Centre, Cairo, Egypt. ${ }^{2}$ Economic Entomol. And Pesticide Dep. Fac. Of Agric., Cairo Univ., Giza, Egypt.

Received: 11 December 2019 Accepted: 2 July 2020

Published online: 23 July 2020

\section{References}

Abd El-Salam AME, Yassen AA, Sahar MZ, Salem SA, El-Aila HI (2015) Role of Pot Marigold as a Companion Plant and Vermicompost in Protecting and Production of Tomato crop from Infestation with Tomatoes Moth in Egypt. Swift. J Agric Res 1(6):60-68

Abd El-Salam AME, Salem SA, El-Kholy MY, Abdel-Rahman RS, Abdel-Raheem MA (2019) Role of the olive fly, Bactrocera oleae (Rossi) traps in integrated pest management on olive trees under Climatic change conditions in Egypt, Plant Archives, 19, Supplement (2), 457-461.

Abdelmaksoud NM (2019) Control of tomato leafminer, Tuta absoluta (Meyrick) using chemical and eco-friendly insecticides. Ph.D. Faculty of Agriculture, Cairo University, $190 \mathrm{pp}$

Ayalew G (2015) Efficacy of selected insecticidesagainst the South American tomato moth, Tuta absoluta (Meyrick) (Lepidoptera: Gelechiidae) on tomato in the Central Riftvalley of Ethiopia. African Entomology 23:410-417

Aynalem B (2018) Tomato leafminer [Tuta absoluta (Meyrick) (Lepidoptera: Gelechiidae)] and its current ecofriendly management strategies: A review. J Agric Biotech Sustain Dev 10(2):11-24

Babar TK, Hasnain M, Aslam A, Ali Q, Ahmad KJ, Ahmad A, Shahid M (2016) Comparative bioefficacy of newer insecticides against tomato fruit borer, Helicoverpa armigera (Hubner) on tomato crop under field conditions. Pak Ento 38(2):115-122

Bassi A, Roditakis E, Flier WG (2016) The first cases of diamide-resistant Tuta absoluta (Meyrick) and the alternation of the insecticidal modes of action as 
a key IPM practice for sustainable control Alternation of the insecticidal modes of action as a key IPM practice for sustainable control. IOBC/WPRS Bulletin 119:13-20

Benvenga SR, Fernandes OA, Gravena S (2007) Decision making for integrated pest management of the South American tomato pinworm based on sexual pheromone traps. Hortic Bras 25(2):164-169

Berxolli A, Shahini S (2018) Controlling Tuta absoluta (Meyrick, 1917) based on emamectin benzoate usage. EJPAS 6(2):1-6

Biondi A, Guedes R, Wan F (2018) Ecology, Worldwide Spread, and Management of the Invasive South American Tomato Pinworm, Tuta absoluta: Past, Present, and Future. Annu Rev Entomol 63:239-258 https://doi.org/10.1146/ annurev-ento-031616

Birhan A (2018) Tomato leafminer Tuta absoluta (Meyrick) (Lepidoptera: Gelechiidae) and its current ecofriendly management strategies: A review. Journal of Agricultural Biotechnology and Sustainable Development 10(2): 11-24 https://doi.org/10.5897/JABSD2018.0306

Braham M (2014) Role of trap colors and exposure time of pheromone on trapping efficacy of males of the tomato leafminer, Tuta absoluta (Meyrick, 1917) (Lepidoptera: Gelechiidae). Afr J Agric Res 9(29):2263-2271

Braham M, Glida-Gnidez H, Hajji L (2012) Management of the tomato borer, Tuta absoluta in Tunisia with novel insecticides and plant extracts. Bulletin OEPP/ EPPO Bulletin 42(2):291-296

Chegini SG, Abbasipour H (2017) Chemical composition and insecticidal effects of the essential oil of cardamom, Elettaria cardamomum on the tomato leaf miner, Tuta absoluta. Toxin Rev 36(1):12-17

Chidege M, Abel J, Afonso Z, Tonini M, Fernandez B (2017) Tomato leaf miner, Tuta absoluta (Meyrick) (Lepidoptera: Gelechiidae) detected in Namibe Province Angola. Journal of Applied Life Sciences International 12(4):1-5 https://doi.org/10.9734/JALSI/2017/33725

Dayaram DM (2014) Bio-efficacy of New Molecule Against Shoot and Fruit Borer, leucinodes orbonalis (Guen.) on Brinjal. Ph. D. Thesis, Fac. Agric. Pune, Maharashtra State, India, $81 \mathrm{p}$.

Deshpande PP, Deshmukh AJ, Sawai HR (2010) Economic viability of insecticides against Leucinodes orbonalis (Guen.) on brinjal. J of Soil and Crop 20(1):140143

El-Aassar MR, Soliman MHA, Elaal AAA (2015) Efficiency of sex pheromone traps and some bio and chemical insecticides against tomato borer larvae, Tuta absoluta (Meyrick) and estimate the damages of leaves and fruit tomato plant. Ann Agric Sci 60(1):153-156

FAOSTAT (2017). FAO Statistical Database (FAOSTAT). Retrieved April 11, 2018, from http://www.fao.org/faostat.

Gacemi A, Guenaoui Y (2012) Efficacy of emamectin benzoate on Tuta absoluta Meyrick (Lepidoptera: Gelechiidae) infesting a protected tomato crop in Algeria. Acad J Entomol 5(1):37-40. https://doi.org/10.5829/idosi.aje.2012.5.1. 6315

Ghoneim K (2014) Parasitic insects and mites as potential biocontrol agents for a devastive pest of tomato, Tuta absoluta (meyrick) (lepidoptera: gelechiidae) in the world: A Review. 19(4): 36-68.

Giorgini M, Guerrieri E, Cascone P, Gontijo L (2018) Current Strategies and Future Outlook for Managing the Neotropical Tomato Pest Tuta absoluta (Meyrick) in the Mediterranean Basin. Neotropical entomology, 1-17.

Hamdy EMH, El-Sayed W (2013) Efficacy of bio and chemical insecticides in the control of Tuta absoluta (Meyrick) and Helicoverpa armigera (Hubner) infesting tomato plants. Aust J Basic Appl Sci 7(2):943-948

Henderson CF, Tilton EW (1955) Tests with acaricides against the brown wheat mite. J Econ Entomol 48(2):157-161

IRAC (2017) Insecticide Resistance Action Committee. IRAC Mode of Action Classification Scheme [online]. IRAC. Available from: https://www.irac-online. org/documents/moa-classification/?ext=pdf.

IRAC (2019) (Insecticide Resistance Action Committee). IRAC Mode of Action Classification Scheme. Version 9(3):1-30

Kushwaha RK, Sharma NP, Baldodiya VK (2018) Profitability of Tomato (Lycopersi conesculentum) Production in some Selected Areas in Panna District of Madhya Pradesh. Int J Curr Microbiol App Sci 6:2117-2124

Miranda MMM, Picanço MC, Zanuncio JC, Bacci L, Silva ÉM (2005) Impact of integrated pest management on the population of leafminers, fruit borers, and natural enemies in tomato. Ciência Rural, Santa Maria 35(1): 204-208

Moussa S, Sharma A, Baiomy F, Eid El-Adl F (2013) The Status of Tomato Leafminer; Tuta absoluta (Meyrick) (Lepidoptera: Gelechiidae) in Egypt and Potential Effective Pesticides. Acad J Entomol 6(3):110-115
Ndor DC (2018) Incidence of Tomato leaf miner (Tuta absoluta Meyrick) damage on Tomato fields in Pankshin and Kanke Local Government Areas of Plateau State, 8(January), 15-19.

Patra S, Chatterjee ML, Mondal S, Samanta A (2009) Field evaluation of some new insecticides against brinjal shoot and fruit borer, Leucinodes orbonalis (Guen.). Pestic Res J 21(1):58-60

Retta AN, Berhe DH (2015) Tomato leaf miner Tuta absoluta (Meyrick), a devastating pest of tomatoes in the highlands of Northern Ethiopia: A call for attention and action. Res J Agric Environ Man 4(6):264-269

Roditakis E, Vasakis E, García-Vidal L, Martínez-Aguirre M, Rison JL, Haxaire-Lutun MO, Nauen R, Tsagkarakou A, Bielza P (2018) A four year survey on insecticide resistance and likelihood of chemical control failure for tomato leaf miner Tuta absolutain the European/Asian region. J Pest Sci 91:421-435

Salem SA, Abdel-Moniem ASH (2015) Evaluation of non-traditional approaches for controlling tomato moth, Tuta absoluta Meyrick (Lepidoptera, Gelechiidae), a new invasive pest in Egypt. Arch Phytopathol Plant Protect 48(4):319-326

Sammour EA, Kandil MAH, Abdel-Aziz NF, Agamy EAM, El-Bakry AM, Abdelmaksoud NM (2018) Field evaluation of new formulation types of essential oils against Tuta absoluta and their side effects on tomato plants. Acta Scientific Agriculture 2(6):15-22

Sarwar M, Salman M (2015) Toxicity of oils formulation as a new useful tool in crop protection for insect pests control. Int J Mol Sci 1(4):297-302

Shiberu T, Getu E (2017) Effects of crude extracts of medicinal plants in the management of Tuta absoluta (Meyrick) (Lepidoptera: Gelechiidae) under laboratory and glasshouse conditions in Ethiopia. J Entomo Nemato 9:9-13

Shivanna BK, Naik BG, Kumar NG, Nagaraja S, Naika RK (2011) Comparative efficacy of biopesticides and synthetic insecticides against cotton pink bollworm. J of Genetics \& Evolution 4(4):17-32

Silva JE, Assis CP, Ribeiro LM, Siqueira HA (2016) Field-evolved resistance and cross-resistance of Brazilian Tuta absoluta (Lepidoptera: Gelechiidae) populations to diamide insecticides. J Econ Entomol 109:2190-2195

SPSS (2017) Statistical package for the social sciences. 25 edn. Chicago, IL, USA

Sylla S, Brévault T, Bal AB, Chailleux A, Diatte M, Desneux N, Diarra K (2017) Rapid spread of the tomato leafminer, Tuta absoluta (Lepidoptera: Gelechiidae), an invasive pest in Sub-Saharan Africa. Entomologia Generalis 36: 269-283, doi. org/10.1127/entomologia/2017/0453.

Taha AM, Afsah AFE, Fargalla FH (2013) Evaluation of the effect of integrated control of tomato leafminer Tuta absoluta with sex pheromone and insecticides. Nat Sci 11(7):26-29

Tonnang HE, Mohamed SF, Khamis F, Ekesi S (2015) Identification and risk assessmentfor worldwide invasion and spread of Tuta absoluta with a focus on Sub-Saharan Africa: Implications for phytosanitary measures and management. PLOS ONE2015;10:e0135283.

Valchev N, Yankova V, Markova D (2013) Biological activity of plant protection products against Tuta absoluta (Meyrick) in tomato grown in greenhouses. Agric Sci Technol 5(3):318-321

Yang JY, Kim MG, Lee SE, Lee HS (2014) Acaricidal activities against house dust mites of spearmint oil and its constituents. Planta Med 80(2-3):165-170

\section{Publisher's Note}

Springer Nature remains neutral with regard to jurisdictional claims in published maps and institutional affiliations.

\section{Submit your manuscript to a SpringerOpen ${ }^{\circ}$ journal and benefit from:}

- Convenient online submission

- Rigorous peer review

- Open access: articles freely available online

- High visibility within the field

- Retaining the copyright to your article

Submit your next manuscript at $>$ springeropen.com 